\title{
Ewa Jaska
}

Szkoła Główna Gospodarstwa Wiejskiego w Warszawie Instytut Ekonomii i Finansów ewa_jaska@sggw.pl

\section{ODBIÓR SPOŁECZNY PROGRAMU TELEWIZYJNEGO JAKO GŁÓWNE ŹRÓDŁO PRZEWAGI KONKURENCYJNEJ NADAWCÓW}

\author{
Abstract \\ PUBLIC PERCEPTION OF A TV PROGRAM AS A MAJOR SOURCE \\ OF COMPETITIVE ADVANTAGE FOR BROADCASTERS
}

This paper's is to present the importance of the level of public perception of TV program, with particular focus on television genres which contribute to creating the competitive advantage of the station. This study used primary and secondary sources. The original research involved a survey. The survey was conducted at the turn of 2018 and 2019 on a sample of 1249 adult Polish TV viewers. The secondary sources included: telemetry audience measurement reports and reports published by the major TV broadcasters in Poland. The programming of Polish television broadcasters is increasingly market-oriented, both when it comes to commercial and public broadcasters. Films, TV serials, sports broadcasts, entertainment shows and news programs are the key formats which attract satisfying audiences and create competitive advantage. The findings have implications for both the TV stations creating the broadcasting schedules for subsequent seasons and for advertisers making decisions about allocating their media budgets.

Keywords: program, audience, competition, market, television

\section{Wprowadzenie}

Budowanie przewagi konkurencyjnej to działania podejmowane w celu wykorzystania potencjału przedsiębiorstwa i przejawiające się między innymi w efektywnym stosowaniu instrumentów konkurowania. Jest to na przykład zwiększanie 
liczby kanałów udostępniania treści wskutek coraz bardziej popularnego odbioru przesuniętego w czasie i oferowania więcej niż jednego produktu, w tym kanałów tematycznych. Konieczna jest również obecność produktów telewizyjnych na rynkach sąsiadujących wobec zjawiska konwergencji przejawiającej się między innymi w zacieraniu się różnic między poszczególnymi rodzajami mediów.

W warunkach dynamicznych zmian, jakie dokonują się na rynku medialnym, w tym telewizyjnym, możliwe jest jedynie osiąganie chwilowej przewagi konkurencyjnej. Jan Polowczyk stwierdza, że podstawowym celem strategii przedsiębiorstwa staje się kreowanie przewagi w kolejnych okresach, a nie obrona trwałej przewagi (Polowczyk, 2012). W przypadku stacji telewizyjnych możliwości budowania krótkookresowej przewagi konkurencyjnej ujawniają się podczas planowania kolejnych sezonów ramówkowych, wiosennych i jesiennych. Dlatego tak ważne jest zestawianie treści w taki sposób, aby oferta programowa finalna zawierała produkty medialne jak najwyższej wartości, którą indywidualne dobra medialne zyskują przez kontekst, w jakim pojawiają się na rynku.

Wymienione działania powinny także skutkować wyższymi udziałami w rynku reklamy medialnej, wydatki na reklamę telewizyjną stanowią bowiem nadal podstawowe źródło finansowania kolejnych inwestycji programowych i technologicznych nadawców.

\section{Definiowanie źródeł przewagi konkurencyjnej}

Definiując źródła przewagi konkurencyjnej, można przywołać zarówno tradycyjne, jak i nowsze teorie konkurencyjności (Pierścionek, 2006). Autorzy tradycyjnych koncepcji konkurencyjności przedsiębiorstwa wśród mechanizmów i czynników wymieniają w pierwszej kolejności koszty, jakość, marketing, logistykę, pozycję na rynku, specjalizację, dostępność surowców i systemy zarządzania jakością (Włodarczyk, 2013). W ujęciu tradycyjnym podkreśla się dodatkowo występowanie konkurencji oligopolistycznej i monopolistycznej, a także możliwość osiągnięcia stabilnej długookresowej przewagi konkurencyjnej (Macias, 2008). W nowszych koncepcjach uwzględnia się uwarunkowania wynikające ze zmian w otoczeniu, a ich wyróżnikami w pierwszej kolejności stają się innowacje, przedsiębiorczość i powiązania sieciowe przedsiębiorstw tego samego sektora (Żabiński, 2013). W przypadku rynku telewizyjnego zasadne jest zwrócenie uwagi na takie źródła przewagi konkurencyjnej, jak wyróżniające się zasoby i umiejętności, w tym relacje wewnątrz przedsiębiorstwa i z otoczeniem, które w konsekwencji stanowią o zdolności zaspokajania potrzeb odbiorców treści medialnych w większym stopniu niż konkurencja. Takie ujęcie wpisuje się w podstawowe założenia teorii przewagi komparatywnej (przewagi zasobowej), którą w połowie lat 90. XX wieku zaprezentowali Shelby D. Hunt i R.M. Morgan (1996). Według nich istotą konkurowania jest ustawiczna rywalizacja przedsiębiorstw o uzyskanie komparatywnej przewagi w zakresie 
zasobów, co skutkuje pozycją rynkową zapewniającą przewagę w konkretnym segmencie rynku i wyróżniającymi się wynikami ekonomicznymi. W tym ujęciu przewaga konkurencyjna jest definiowana jako wielofazowy proces, na początku którego znajdują się zasoby przedsiębiorstwa przekształcane wskutek oddziaływania różnych czynników w przewagę komparatywną. Oprócz zasobów źródłami przewagi konkurencyjnej są umiejętności i relacje. Na rynku telewizyjnym podstawowe zasobowe źródła przewagi to zasoby programowe i audytorium, chociaż stacje telewizyjne rywalizują o zasoby reklamowe przez odpowiednie kształtowanie polityki cenowej, na rynku praw autorskich, rynku pracy, dystrybucji czy produkcji telewizyjnej, w tym w zakresie cyklu życia produkcji telewizyjnej, czyli możliwości chociażby emisji powtórkowych w zależności od poziomu zainteresowania społecznego. W kategorii umiejętności podstawowe znaczenie mają twórcy i liczny, dobrze zmotywowany personel twórczy, który może zaoferować unikatowe, innowacyjne treści. Wśród najważniejszych relacji należy natomiast wymienić interakcje między stacjami telewizyjnymi a widzami, rynkiem reklamy, organami regulacyjnymi, pośrednikami, producentami audycji i sieciami dystrybucji. Podstawowe procesy zachodzące w stacjach telewizyjnych, takie jak powstawanie zawartości, sprzedaż reklam i dystrybucja zawartości, są warunkowane interakcją środowisk. Tym samym nie jest łatwe wskazanie jednego najistotniejszego źródła przewagi konkurencyjnej, pozycja rynkowa jest bowiem efektem wzajemnych relacji, a zmiana jednego z nich wywołuje kolejne. Współcześnie trudno jest utrzymać przewagę konkurencyjną budowaną wyłącznie na jednym źródle, a także wskazać dwie identyczne stacje telewizyjne, które mają takie same zasoby i w identyczny sposób je wykorzystują.

Poszczególne sektory medialne wyróżniają się procesem produkcji i modelami biznesowymi, ale wspólnym mianownikiem jest tworzenie treści medialnych. Dotychczasowe struktury stają się coraz mniej stabilne, a modele biznesowe coraz mniej aktualne, z uwagi na zakres, tempo i charakter zmian zachodzących w otoczeniu. Organizacje medialne, w tym stacje telewizyjne, podejmują działania zmierzające do zdefiniowania determinant zmian sposobów produkcji, pakietowania i dystrybucji, tradycyjnych audytoriów i reklamowych (Kreft, 2016). Dlatego tak istotne jest zarządzanie zmianą, a nowym jej wymiarem staje się na przykład rynek telewizji subskrypcyjnej wymuszający modyfikację dotychczasowych modeli biznesowych i wdrażanie zasad ekonomii subskrypcji. Skutkuje to również zmianami w zarządzaniu zawartością w stacjach telewizyjnych, ponieważ zmienia się styl korzystania $\mathrm{z}$ oferty telewizyjnej i następuje fragmentacja audytorium (Jaskiernia, Gajlewicz-Korab, 2016). Konsekwencją tego jest między innymi coraz mniejsza popularność czterech głównych kanałów telewizyjnych w Polsce, a większe zainteresowanie kanałami tematycznymi i usługami nielinearnymi. W celu przyciągnięcia uwagi audytorium stacje telewizyjne muszą stopniowo rezygnować z typowych produktów i poszukiwać nowych nisz rynkowych lub stosować nowe technologie, aby poprawić dostępność oferty programowej. Konieczność adaptacji do zmieniającej się technologii zaczyna stanowić kluczowy element funkcjonowania 
przedsiębiorstwa telewizyjnego ze względu na rosnącą popularność nielinearnego odbioru, w szczególności wśród młodego pokolenia.

Zawartość mediów staje się wartością rynkową, jeżeli znajdzie się w kanale dystrybucji i wzbudzi zainteresowanie społeczne, którego poziom jest określany wielkością audytorium. Podobnie sieci dystrybucji nie przedstawiają wartości bez zawartości. Wymienione prawidłowości wynikają między innymi z koncepcji „łańcucha wartości” M.E. Portera. Zgodnie z tą teorią źródłem przewagi konkurencyjnej przedsiębiorstwa jest synergiczna suma poszczególnych aktywności firmy. Każdy typ prowadzonej działalności ma wpływ na jej pozycję na rynku (Nierenberg, 2011). Zarówno faza tworzenia zawartości, jak i pozostałe, takie jak tworzenie pakietów oraz rozpowszechnianie. Lucy Küng wymienia na rynku telewizyjnym tradycyjny łańcuch wartości i łańcuch wartości kształtujący się w branży telewizyjnej, który jest rezultatem między innymi zmian technologicznych, większego popytu na materiały i wprowadzenia usług subskrybowanych. W związku z tym wymieniany jest etap porządkowania i agregacji, który obejmuje dostarczanie materiałów i rozdzielanie ich na poszczególne kanały, aby trafić do konkretnych grup widzów. W kształtującym się łańcuchu wartości wymienia się także interfejs, czyli ogniwo pozwalające na nawiązanie bezpośredniej relacji z odbiorcą treści za pomocą nowych rozwiązań technologicznych na poziomie dekoderów i oprogramowania sterującego sprzętem oraz zapewniającego dostęp użytkownika. Przykładem jest system dostępu warunkowego w udostępnianiu usług interaktywnych bądź elektroniczny przewodnik po programach, który pozwala widzom na dokonywanie wyborów pozycji programowych z szerokiej oferty telewizyjnej (Küng, 2012).

\section{Metodyka badań}

Celem artykułu jest przedstawienie znaczenia poziomu odbioru społecznego programu telewizyjnego, a w szczególności rodzajów audycji telewizyjnych, w budowaniu przewagi konkurencyjnej stacji. Przeprowadzone analizy i ich wyniki dotyczą polskiego rynku telewizyjnego.

Wiosną 2018 roku przeprowadzono badania pilotażowe wśród 141 respondentów i tym samym zweryfikowano pierwotną wersję kwestionariusza ankiety, aby przystąpić do badań właściwych. Badania pilotażowe zrealizowano za pośrednictwem formularza online. W badaniach właściwych przeprowadzonych na przełomie 2018/2019 wykorzystano metodę sondażu diagnostycznego i zastosowano w doborze populacji metodę kuli śniegowej (Johnson, 2014). Jest to metoda nielosowego doboru próby polegająca na pozyskiwaniu respondentów przez innych respondentów. Badacze używają tej metody, kiedy trudno jest dotrzeć do uczestników do badania, a w prezentowanym badaniu niezbędne było dotarcie do różnych grup wiekowych, mieszkańców miast różnej wielkości, o zróżnicowanych dochodach i legitymujących się różnym poziomem wykształceniem. 
W kwestionariuszu ankiety sformułowano między innymi pytania o preferowane audycje telewizyjne, najchętniej oglądane serwisy informacyjne i motywy skłaniające do oglądania telewizji. Jest to część pytań badawczych, które zostały zawarte $\mathrm{w}$ szerszym badaniu dotyczącym zmian w korzystaniu $\mathrm{z}$ telewizji i ich uwarunkowań. Wprawdzie dostępne są wyniki badań telemetrycznych Nielsen Audience Measurement, to jednak cenne jest pozyskiwanie kolejnych informacji ilustrujących zmiany w korzystaniu z treści telewizyjnych z uwagi chociażby na pojawiającą się obecnie w przestrzeni publicznej krytykę telemetrii. Poziom zainteresowania społecznego poszczególnymi pozycjami programu telewizyjnego jest istotnym źródłem przewagi konkurencyjnej, dlatego prowadzenie tego typu badań nie traci na ważności i aktualności, w szczególności w obszarze zmian postaw widzów i ich preferencji. Każde kolejne wyniki badań, w tym prezentowane, są źródłem nowych informacji, które mogą być wykorzystywane w poszukiwaniu nisz rynkowych.

W badaniu uczestniczyło 1249 pełnoletnich Polaków oglądających telewizję. Kobiety stanowiły większość grupy badawczej $(63,5 \%)$. W kategorii wiek $51,8 \%$ to osoby młode - 18-35 lat. Grupę widzów reprezentowały głównie osoby z wykształceniem średnim (66,9\%), w drugiej kolejności z wyższym (24,7\%), a następnie pracownicy szczebla średniego i studenci. Najmniej natomiast było osób należących do kadry kierowniczej. Widzowie uczestniczący w badaniu to zarówno mieszkańcy wsi (38,5\%), jak i największych miast, powyżej 200 tys. (28,6\%). Niemal 40\% wskazało na telewizję publiczną i były to głównie osoby w wieku 36+ (66\%), legitymujące się wykształceniem średnim $(63,8 \%)$ i mieszkające na wsi $(49,8 \%)$. Wśród widzów oglądających telewizje komercyjne najwięcej było osób młodych w wieku 18-35 lat (63,4\%), z wykształceniem średnim (69\%) i co trzeci mieszkał w największym mieście. Założono, że wiek jest determinantą zainteresowania programem telewizyjnym i w związku z tym wyodrębniono do dalszych analiz dwie grupy, a mianowicie osoby mające 18-35 lat i 36+. Tych, dla których ofertą pierwszego wyboru stają się media społecznościowe, i tych, którzy stopniowo rezygnują z mediów tradycyjnych. Nie planowano w ramach badania porównywania z grupami wiekowymi wyodrębnionymi w badaniu Nielsena, które w pierwszej kolejności są istotne dla reklamodawców.

W artykule wykorzystano także źródła wtórne, takie jak raporty telemetryczne Nielsen Audience Measurement i materiały źródłowe głównych nadawców telewizyjnych w Polsce.

\section{Program i audytorium - wyniki badań}

W obszarze zarządzania zawartością i budowania przewagi konkurencyjnej jednym $\mathrm{z}$ ważniejszych instrumentów jest proces programowania. Jego istota sprowadza się do tworzenia takiego układu ramowego, aby zainteresować swoją ofertą jak największe audytoria. Błędy popełniane przy konstruowaniu ramówek, w sytuacji 
zwiększających się dla widzów możliwości wyboru, skutkują niższymi wskaźnikami oglądalności, a tym samym mniejszymi wpływami reklamowymi. Wydatki na reklamę telewizyjną stanowią nadal podstawowe źródło finansowania kolejnych inwestycji programowych i technologicznych nadawców, a udostępnianie audytorium w zamian za pozyskiwanie przychodów od reklamodawców to podstawa, na której opiera się model biznesowy przedsiębiorstwa telewizyjnego, a koncentrowanie uwagi odbiorców mediów staje się cennym dobrem, o które konkuruje coraz więcej mediów.

Sprzedaż czasu reklamowego, a zarazem uzupełnianie zawartości, jest jednym $\mathrm{z}$ czterech podstawowych procesów - obok wytwarzania i dystrybucji treści oraz interakcji widzów - w obszarze zarządzania zawartością w przedsiębiorstwie telewizyjnym. W I kwartale 2018 roku stacja Polsat w największym stopniu wypełniła limit 12 minut (niemal 100\%), TVN na poziomie 97\%, a w najmniejszym TVP1 (średnio 79\%). W 2019 roku wszystkie kanały wielkiej czwórki w mniejszym stopniu wykorzystały limit ustawowy, a w szczególności TVP2 (77\%, czyli spadek o 4 pkt proc.), co może wynikać z niższej oglądalności produkcji serialowych, a w przypadku wzrostu TVP1 (do poziomu $80 \%$ ) jest to rezultat nabycia praw do ważnych wydarzeń sportowych. W Polsacie był to spadek do 99\% (1 pkt proc.), a w TVN do 89\% (mniej o 8 pkt proc.) (Goczał, 2019). Poziom odbioru społecznego oferowanych pozycji programowych i ich następstwo są podstawą do opracowywania cenników spotów reklamowych w poszczególnych pasmach emisyjnych i sezonach. Dobrym przykładem zróżnicowania cen spotów 30-sekundowych i ich zależności od poziomu oglądalności są dwa pasma zaprezentowane w tabeli 1, czyli czas emisji w godzinach 19:00-22:00 i 2:00-5:00.

Tabela 1. Ceny spotu reklamowego 30-sekundowego w pasmach najwyższej i najniższej oglądalności w kwietniu 2019 roku [zł]

\begin{tabular}{|l|l|l|l|}
\hline Pasmo [godz.] & TVP & TVN & Polsat \\
\hline 19:00-22:00 & $38500,00-78300,00$ & $48500,00-73100,00$ & $45100,00-73800,00$ \\
\hline 02:00-05:00 & $500,00-800,00$ & $1200,00-4800,00$ & $2200,00-3000,00$ \\
\hline
\end{tabular}

Źródło: dane cennikowe nadawców.

Najwyższa cena w TVP był przy serialu M jak miłość, w stacji TVN przy formacie Kuchenne rewolucje, a w Polsacie przy serialu Przyjaciótki.

Jak wynika z raportów finansowych TVP, TVN i Polsat, udziały głównych grup medialnych w rynku reklamy telewizyjnej wynosiły w 2007 roku niemal 95\%. W 2017 roku spadły do poziomu 82\% przy jednoczesnym wzroście udziału pozostałych nadawców telewizyjnych do wysokości niemal 18\%. Największy spadek, bo niemal dwukrotny, odnotowano w grupie medialnej TVP. W grupie Polsat 
wystąpiła tendencja wzrostowa do poziomu 27\%, a przychody reklamowe grupy TVN w analizowanym okresie można zdefiniować jako najbardziej stabilne i oscylujące w przedziale 35-39\%. Jest to także rezultat zmian w obszarze zachowań odbiorców, którzy rezygnują z głównych anten na rzecz innych stacji dostępnych $\mathrm{w}$ ofercie naziemnej telewizji cyfrowej i w rezultacie zmniejsza się audytorium. $\mathrm{Na}$ uwagę zasługuje rok 2013, w którym ukończono proces wdrażania naziemnej telewizji cyfrowej, i wtedy według danych KRRiTV wpływy reklamowe czterech głównych kanałów (TVP1, TVP2, Polsat i TVN) były mniejsze o 12,3\% niż rok wcześniej, ponieważ zyskali (o 18\%) główni beneficjenci procesu cyfryzacji, czyli TV4, TVN7 i TV Puls (Raporty finansowe TVP, TVN, Polsat, 2007-2017).

$\mathrm{Z}$ dotychczasowych danych publikowanych $\mathrm{w}$ raportach telemetrycznych wynika, że największe audytoria gromadzą transmisje $\mathrm{z}$ ważnych wydarzeń sportowych, seriale i filmy, formaty rozrywkowe i serwisy informacyjne (Jaska, Werenowska, 2017). Dobrym przykładem jest ranking 10 najchętniej oglądanych audycji w latach 2016-2018 (tabela 2).

W 2016 roku w rankingu Top 10 audycji dziewięć z nich to transmisje meczów piłki nożnej emitowanych w TVP i Polsacie (pięć było wyemitowanych przez TVP1, cztery przez Polsat). W prezentowanym zestawieniu jedyną pozycją inną niż sportowa jest serial M jak miłość pokazywany na antenie TVP2. W 2017 roku na pierwszym miejscu znalazł się Polsat, pokazując eliminacje mistrzostw świata, a na drugim TVP1 (trzy konkursy narciarskie w ramach Pucharu Świata i Teleexpress). Istotne różnice można zaobserwować w 2018 roku, ponieważ na liście 10 audycji telewizyjnych, które zgromadziły największe audytorium, było dziewięć pozycji TVP1 (mistrzostwa świata i konkurs narciarski, Teleexpress) i jedna pozycja TVP2, czyli serial $M$ jak miłość. Zabrakło stacji Polsat, która nie nabyła praw do ważnych transmisji sportowych rozgrywanych w tym roku, i jest to bardzo dobra ilustracja sytuacji, w której posiadanie praw do ważnych transmisji sportowych staje się źródłem przewagi konkurencyjnej.

Audycje sportowe wskazano w badaniu ankietowym na miejscu trzecim, za formatami muzycznymi i filmem. Jest to zapewne rezultat tego, że pytanie dotyczyło przekazów sportowych ogółem, bez wyszczególnienia transmisji z ważnych wydarzeń europejskich i światowych oraz dyscyplin. Należy zauważyć, że w zaprezentowanym rankingu Top 10 były to mecze piłki nożnej rozgrywane podczas mistrzostw świata i Europy oraz skoki narciarskie. W literaturze przedmiotu zwraca się uwagę na to, że jedną z determinant różnicujących preferencje widzów jest wiek i dlatego postanowiono zweryfikować tę zależność w grupie 18-35 lat oraz 36 lat i więcej. 


\begin{tabular}{|c|c|c|c|c|c|c|c|c|c|c|c|}
\hline & 䍃 & mे & $\frac{m}{n}$ & \begin{tabular}{l}
$\stackrel{n}{n}$ \\
\multirow{6}{0}{}
\end{tabular} & $\begin{array}{l}\exists \\
\stackrel{+}{4}\end{array}$ & $\begin{array}{l}\hat{0} \\
\hat{i} \\
\text { กิ }\end{array}$ & $\vec{F}$ & $\begin{array}{l}\text { î } \\
\text { in }\end{array}$ & \begin{tabular}{l}
\multirow{2}{*}{} \\
$\hat{\sigma}$
\end{tabular} & $\begin{array}{l}\hat{n} \\
\text { ô } \\
+\end{array}$ & $\stackrel{\text { f }}{\vec{F}}$ \\
\hline & 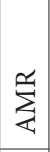 & 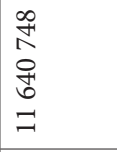 & 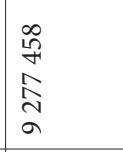 & 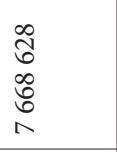 & 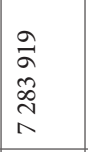 & $\begin{array}{l}0 \\
1 \\
0 \\
0 \\
10 \\
\infty \\
0\end{array}$ & $\begin{array}{l}8 \\
\stackrel{1}{0} \\
m \\
\vdots \\
0\end{array}$ & \begin{tabular}{l}
$\hat{⿵}$ \\
$\infty$ \\
$\exists$ \\
\multirow{H}{*}{} \\
0
\end{tabular} & 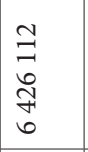 & $\begin{array}{l}\text { P } \\
\text { in } \\
\text { ôे } \\
\text { +1 } \\
0\end{array}$ & $\begin{array}{l}1 \\
o \\
\infty \\
2 \\
o+1 \\
0\end{array}$ \\
\hline$\stackrel{\infty}{\stackrel{\sim}{*}}$ & 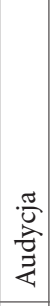 & 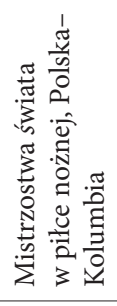 & 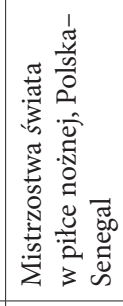 & 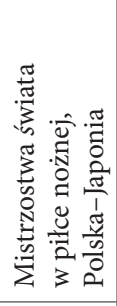 & 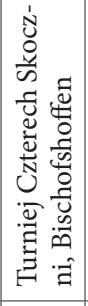 & 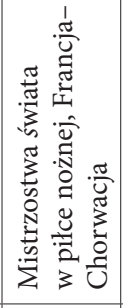 & 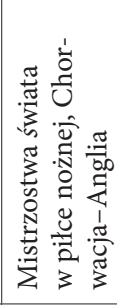 & 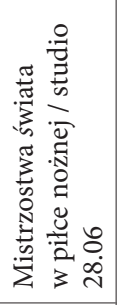 & 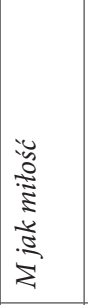 & 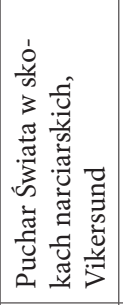 & 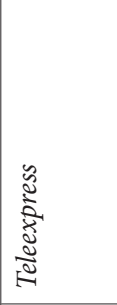 \\
\hline & 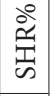 & $\begin{array}{l}\hat{\alpha} \\
\text { กิ }\end{array}$ & $\begin{array}{l}\text { i } \\
\text { s. } \\
\text { in }\end{array}$ & \begin{tabular}{l}
$\infty$ \\
\multirow{2}{+}{} \\
$\stackrel{4}{4}$
\end{tabular} & $\begin{array}{l}\widehat{F} \\
\vec{F}\end{array}$ & $\begin{array}{l}\hat{O} \\
\hat{F}\end{array}$ & $\begin{array}{l}\infty \\
\stackrel{\infty}{\hat{f}} \\
\dot{f}\end{array}$ & $\begin{array}{l}\infty \\
\infty \\
\hat{m}^{\infty}\end{array}$ & \begin{tabular}{l}
$N$ \\
\multirow{2}{*}{+}
\end{tabular} & $\begin{array}{l}\stackrel{1}{9} \\
\stackrel{9}{9}\end{array}$ & $\begin{array}{l}\stackrel{\infty}{\hat{\alpha}} \\
\hat{\mathrm{m}}\end{array}$ \\
\hline & 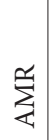 & \begin{tabular}{l}
10 \\
$\infty$ \\
$i$ \\
2 \\
\multirow{+}{2}{} \\
$\infty$
\end{tabular} & $\begin{array}{l}\infty \\
\infty \\
\infty \\
\hat{n} \\
N \\
\sim\end{array}$ & $\begin{array}{l}\hat{L} \\
\stackrel{2}{N} \\
\stackrel{-}{N} \\
N\end{array}$ & $\begin{array}{l}\hat{\jmath} \\
\hat{\jmath} \\
o \\
a \\
b\end{array}$ & $\begin{array}{l}0 \\
\stackrel{0}{1} \\
\text { m } \\
\infty \\
\infty \\
0 \\
0\end{array}$ & 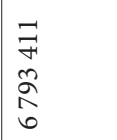 & 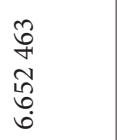 & \begin{tabular}{l}
0 \\
$\infty$ \\
$\infty$ \\
$\stackrel{2}{7}$ \\
\multirow{1}{*}{}
\end{tabular} & 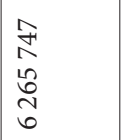 & $\begin{array}{l}\hat{a} \\
\widehat{a} \\
\text { in }\end{array}$ \\
\hline 공 & $\mid \begin{array}{l}\frac{0}{0} \\
\frac{0}{2} \\
\frac{3}{4}\end{array}$ & 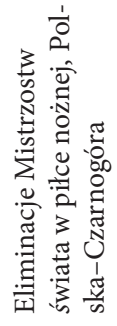 & 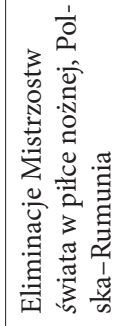 & $\frac{\tilde{\omega}}{\frac{\tilde{c}}{5}}$ & 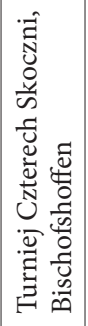 & 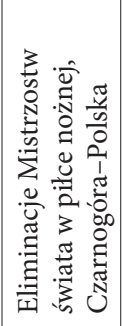 & 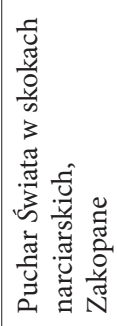 & 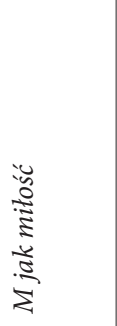 & 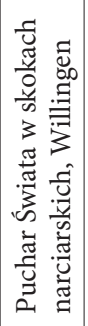 & 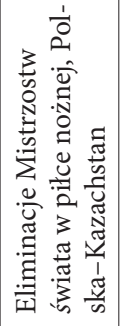 & 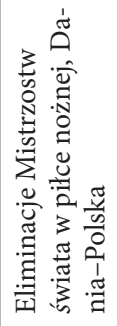 \\
\hline & 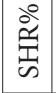 & $\begin{array}{l}\vec{D} \\
\stackrel{2}{+}\end{array}$ & \begin{tabular}{l}
$\infty$ \\
0 \\
\multirow{f}{*}{}
\end{tabular} & \begin{tabular}{l}
\multirow{2}{*}{} \\
fô
\end{tabular} & $\begin{array}{l}0 \\
\text { in } \\
\text { if }\end{array}$ & $\begin{array}{l}\stackrel{R}{\hat{f}} \\
\hat{f}\end{array}$ & $\begin{array}{l}\text { त̃ } \\
\text { ले }\end{array}$ & $\begin{array}{l}\hat{n} \\
\stackrel{\sim}{+}\end{array}$ & $\begin{array}{l}\text { ָे } \\
\text { fे }\end{array}$ & $\begin{array}{l}\infty \\
\infty \\
\infty \\
m\end{array}$ & $\begin{array}{l}\tilde{1} \\
\tilde{\rho}^{0}\end{array}$ \\
\hline & 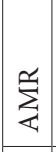 & 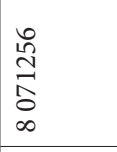 & $\begin{array}{l}\infty \\
\infty \\
0 \\
m \\
\curvearrowright \\
n \\
n\end{array}$ & $\begin{array}{l}0 \\
\ddots \\
\infty \\
\widehat{\sigma} \\
\wedge\end{array}$ & $\begin{array}{l}0 \\
i \\
i n \\
\infty \\
0 \\
0 \\
1\end{array}$ & $\begin{array}{l}\tilde{\sigma} \\
\tilde{n} \\
\sigma \\
\sigma \\
\sigma\end{array}$ & $\begin{array}{l}7 \\
\infty \\
+ \\
\infty \\
\infty \\
0\end{array}$ & $\begin{array}{l}\stackrel{+}{N} \\
\infty \\
\stackrel{N}{N} \\
0\end{array}$ & $\begin{array}{l}\vec{i} \\
\text { N } \\
\text { in } \\
0\end{array}$ & \begin{tabular}{l} 
I \\
\multirow{H}{*}{} \\
J \\
0
\end{tabular} & $\begin{array}{l}8 \\
\infty \\
0 \\
0 \\
0 \\
0 \\
0\end{array}$ \\
\hline$\stackrel{0}{\stackrel{0}{0}}$ & 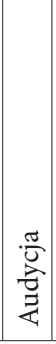 & 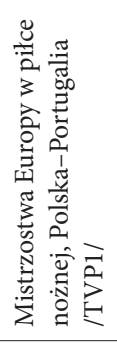 & 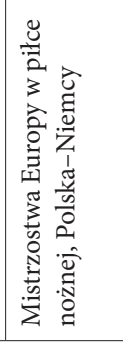 & 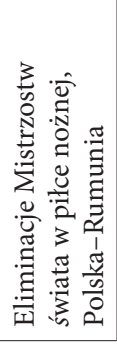 & 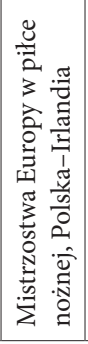 & 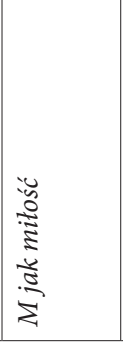 & 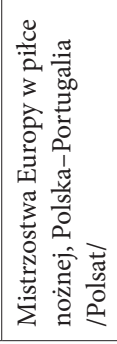 & 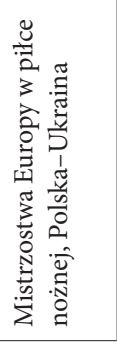 & 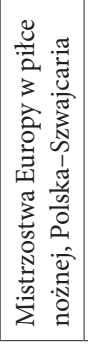 & 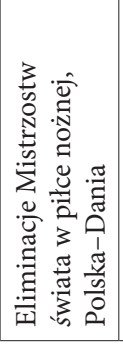 & 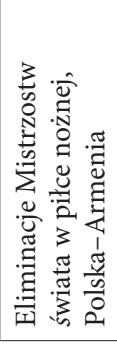 \\
\hline
\end{tabular}


Rysunek 1. Audycje telewizyjne preferowane w grupie wiekowej 18-35 lat i 36+ [\%]

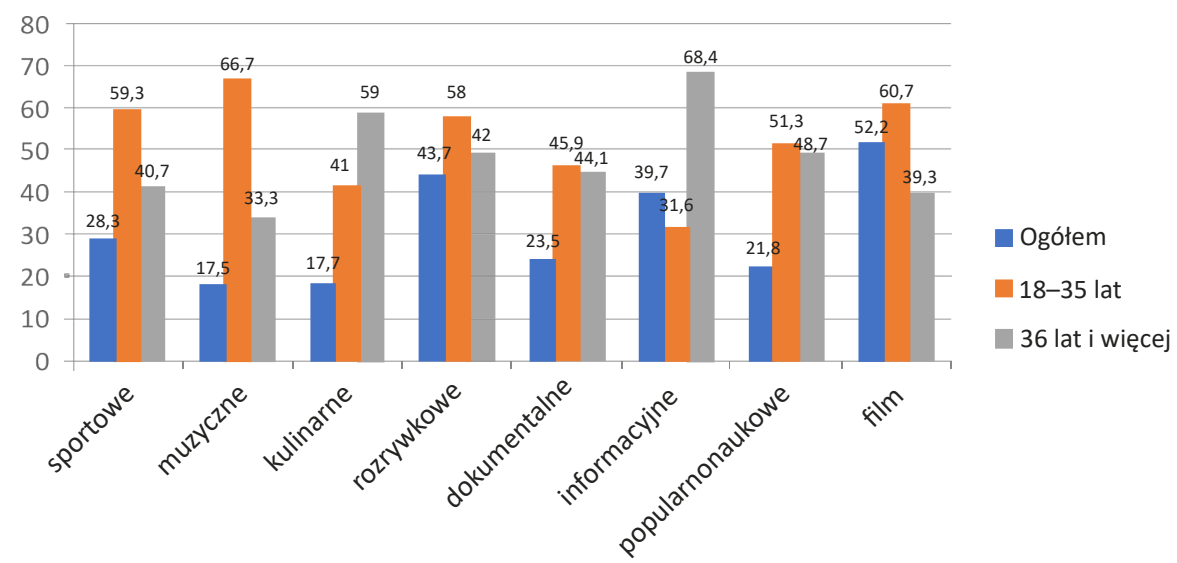

* Badany mógł wskazać więcej niż jedną odpowiedź.

Źródło: wyniki badań własnych.

Osoby $\mathrm{z}$ grupy wiekowej $18-35$ lat preferują $\mathrm{w}$ telewizji audycje muzyczne $(66,7 \%)$, film $(60,7 \%)$ i audycje sportowe $(59,3 \%)$. Osoby starsze natomiast interesują w pierwszej kolejności serwisy informacyjne (68,4\%), następnie film (59,3\%) i formaty kulinarne (59\%). Zauważalna różnica w kategorii audycje informacyjne jest zapewne rezultatem tego, że dla osób młodszych źródłem informacji staje się internet. W całej populacji badawczej na trzech pierwszych miejscach znalazły się takie formaty, jak film, rozrywka i informacja (rysunek 1).

Najwięcej respondentów wskazało na Wiadomości (27,9\%), następnie Fakty $(22,7 \%)$ i Wydarzenia $(15,7 \%)$ (rysunek 2). Główny serwis informacyjny TVP jest oglądany chętniej przez osoby w wieku $36+(55 \%)$, a serwisy stacji komercyjnych przez grupę wiekową 18-36 lat (59\%). Również te wyniki potwierdzają obserwowane od kilku lat wyniki badań porównawczych głównych serwisów informacyjnych, chociaż odnotowywane były także okresy, w których na pozycji lidera były Fakty, w szczególności w grupie wiekowej 16-49 lat. Audytorium Wiadomości w grupie badawczej było reprezentowane w pierwszej kolejności przez mieszkańców wsi (46,7\%), następnie miast do 50 tys. (21,2\%) i co piątego mieszkańca miast największych. Podobny odsetek mieszkańców wsi wskazał na Wydarzenia emitowane przez stację Polsat (45,6\%), a najmniej na Fakty, i jest to niewątpliwie też rezultat wcześniejszego zasięgu technicznego tego nadawcy, który bardzo długo był niedostępny dla mieszkańców obszarów wiejskich z uwagi na rozsył sygnału telewizyjnego w technice analogowej. 
Rysunek 2. Najchętniej oglądane audycje informacyjne [\%]

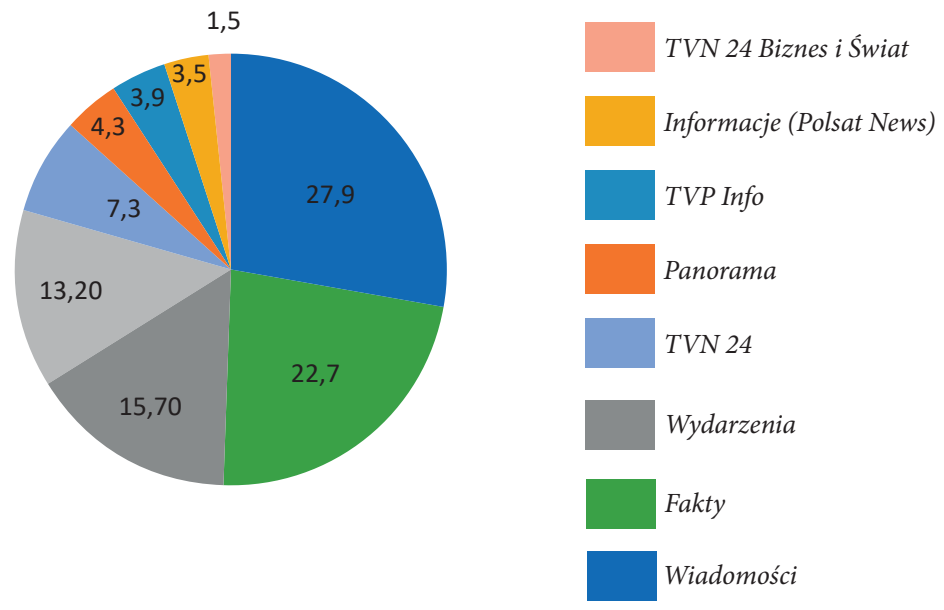

Źródło: wyniki badań własnych.

Rysunek 3. Motywy skłaniające do oglądania telewizji [\%]

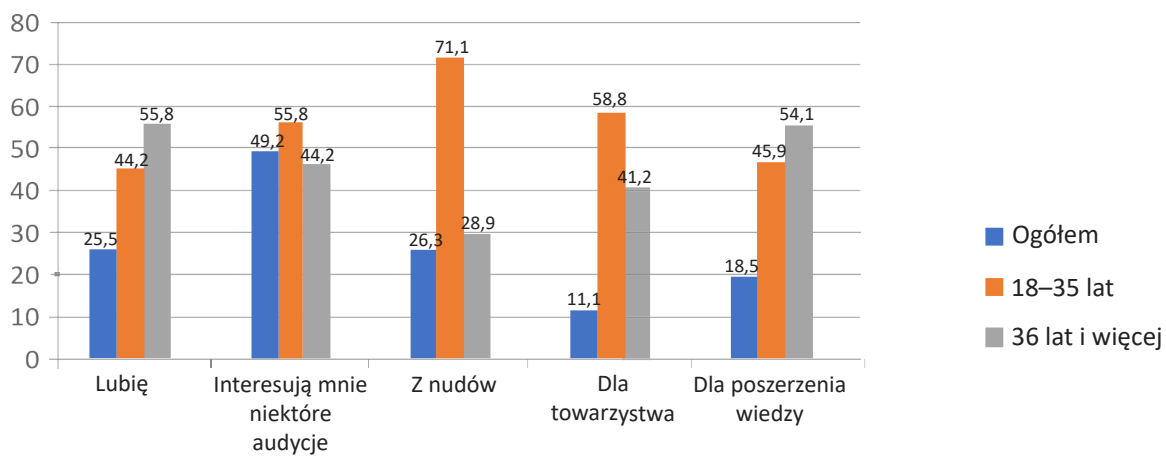

* Badany mógł wskazać więcej niż jedną odpowiedź.

Źródło: wyniki badań własnych. 
Na pytanie o powody, dla których respondenci oglądają telewizję, niemal połowa respondentów stwierdziła, że z zainteresowania niektórymi filmami i audycjami (rysunek 3). W tej kategorii było więcej wskazań osób w wieku 18-35 lat, i tym samym jest to podpowiedź dla osób programujących ofertę na kolejne sezony o wnikliwe rozpoznawanie zainteresowań widza, aby gromadzić przed odbiornikami satysfakcjonującej wielkości audytoria. Co czwarty respondent wskazał na odpowiedź „z nudów” i był to główny powód dla osób w wieku 18-35 lat (71\%). Motywy wymieniane w pierwszej kolejności przez osoby starsze to: bo lubię, dla poszerzenia wiedzy i zainteresowania dla wybranych pozycji programowych. Osoby młodsze wskazywały na znudzenie, towarzystwo i zainteresowanie.

Istotnym źródłem przewagi konkurencyjnej jest także cykl życia produkcji telewizyjnej, czyli możliwość chociażby emisji powtórkowych w zależności od popularności poszczególnych pozycji programowych. Dobrym przykładem może być kanał tematyczny TVP seriale, którego oferta została zbudowana na podstawie bogatych archiwalnych zasobów serialowych nadawcy publicznego. Jak wynika $z$ analiz telemetrycznych, kanał ten znajdował się w ostatnich latach w czołówce wyspecjalizowanych programów telewizyjnych tuż za kanałami informacyjnymi TVN 24, TVP INFO, TTV. W grupie wiekowej 4+ udziały mierzone wskaźnikiem SHR wynosiły w sierpniu 2017-2018 około 1,5\%, a grupie wiekowej 16-49 lat były nawet nieznacznie wyższe (1,8\%) (Kurdupski, 2019).

\section{Podsumowanie}

Polacy nadal oglądają telewizję, chociaż korzystają z tej oferty medialnej inaczej. Wzrasta przede wszystkim liczba kanałów telewizji tradycyjnej, a dodatkowo konkurencja telewizji na życzenie (Netflix i Amazon). Widz wykorzystuje większą liczbę urządzeń do odbioru, czyli na przykład telefon, tablet. W konsekwencji tych zmian nadawca w coraz mniejszym stopniu decyduje o tym, co i kiedy oglądają widzowie, a reklamodawcy uważnie śledzą te zmiany, aby odpowiednio dotrzeć do swoich grup docelowych. Jak wynika $\mathrm{z}$ badania ankietowego, wiek jest czynnikiem różnicującym wybory treści. Osoby w wieku 18-35 lat preferują audycje muzyczne, film i sport, a osoby 36+ film, rozrywkę i informację. Dlatego konstruowanie oferty produktowej powinno być poprzedzone zdefiniowaniem wieku grupy docelowej.

Uprawnione staje się zatem stwierdzenie, że w warunkach zachodzących zmian i w celu budowania przewagi konkurencyjnej oferta programowa powinna gromadzić satysfakcjonujące audytoria, także z punktu widzenia reklamodawców. Należałoby zatem zwiększyć liczbę audycji zorientowanych na rynek, takich jak seriale, transmisje z ważnych rozgrywek sportowych czy formaty rozrywkowe, ale także oferować serwisy informacyjne wielowymiarowo opisujące rzeczywistość obiektywnie istniejącą. 
Chociaż program i audytorium to podstawowe instrumentarium konkurowania, to jednak należy pamiętać, że źródłem przewagi konkurencyjnej jest synergiczna suma aktywności, i każdy rodzaj prowadzonej działalności ma wpływ na pozycję stacji telewizyjnej na rynku.

\section{Bibliografia}

Goczał B. (2019). W Polsacie po 12 min reklam na godzinę, mocno w dół TVN. Koniunktura ostabła, stacje przeszacowaty oczekiwania. Pobrane z: https://www.wirtualnemedia.pl/artykul/jak-dlugo-trwaja-reklamy-w-polsacie-tvn-i-tvp-w-2019-roku-zmalal-popyt-na-reklame-tv (dostęp: 12.04.2019).

Hunt S.D. (2000). A General Theory of Competition: Resources, Competence, Productivity, Economic Growth. London-New Delhi-Thousand Oaks: Sage Publications.

Hunt S.D., Morgan R.M. (1996). The Resource-Advantage Theory of Competition: Dynamics, Path Dependencies and Evolutionary Dimensions. „Journal of Marketing”, 60(3).

Jaska E., Werenowska A. (2017). Komunikacja przedsiębiorstwa $z$ otoczeniem $w$ gospodarce opartej na wiedzy. Warszawa: Wydawnictwo SGGW.

Jaskiernia A., Gajlewicz-Korab K. (red.). (2016). Publiczność mediów w epoce cyfrowej. Warszawa: Oficyna Wydawnicza Aspra-JR.

Johnson T.P. (2014). Snowball Sampling: Introduction. WileyStatsRef: Statistics Reference. Pobrane z: https://onlinelibrary.wiley.com/doi.epdf/10.002/978111445112.stat05720 (dostęp: 28.11.2019).

Kreft J. (2016). Luka niedoboru a media publiczne - szanse i zagrożenia. „Zarządzanie Mediami", 4(3), s. 181-191. DOI:10.4467/23540214ZM.16.009.6296.www.ejournals.eu/ZM.

Küng L. (2012). Strategie zarządzania na rynku mediów. Tłum. P. Jabłoński. Warszawa: Oficyna a Wolters Kluwer Business.

Kurdupski M. (2019). TVN 24 i TTV liderami stacji tematycznych $w$ sierpniu. Rosna TVP Sport i TVP ABC, traca TVP Info i TVP Rozrywka (top 25). Pobrane z: www.wirtualnemedia.pl/ artykul/top-25-kanalow-tematycznych-sierpien-2018-ogladalnosc-TVN24TTV (dostęp: 26.10.2019).

Macias J. (2008). Nowe koncepcje przewagi konkurencyjnej współczesnych przedsiębiorstw. „Przegląd Organizacji”, 9, s. 11-14.

Nierenberg B. (2011). Zarządzanie mediami. Ujęcie systemowe. Kraków: Wydawnictwo Uniwersytetu Jagiellońskiego.

Pierścionek Z. (2006). Współczesne koncepcje konkurencyjności przedsiębiorstwa. W: Z. Pierścionek, S. Jurek-Stępień (red.). Czynniki sukcesu polskich przedsiębiorstw na rynkach Unii Europejskiej. Warszawa: Szkoła Główna Handlowa. Oficyna Wydawnicza.

Polowczyk J. (2012). Zarzadzanie strategiczne w przedsiębiorstwie w ujęciu behawioralnym. Poznań: Wydawnictwo Uniwersytetu Ekonomicznego w Poznaniu.

Raporty finansowe TVP, TVN, Polsat (2007-2017).

Włodarczyk T.M. (2013). Źródła przewagi konkurencyjnej przedsiębiorstwa - aktualny stan dyskusji. W: E. Walińska (red. nauk.). Ekonomia i zarzadzanie w teorii i praktyce. T. 7: Wspótczesne problemy finansów, rachunkowości i zarządzania, s. 266-282. Łódź: Wydawnictwo Uniwersytetu Łódzkiego. DOI: http://dx.doi.org/10.18778/7525-962-9.20.

Żabiński R. (2013). Źródła przewagi konkurencyjnej na rynku medialnym. „Nauki o Zarządzaniu. Management Sciences", 2(15), s. 151-165. 